\title{
Pengertian Antropologi Hukum Menurut Para Ahli Indonesia dan Dunia dalam Mendukung Perkembangan Antropologi Hukum
}

\author{
Rizki Aditya Afela \\ rizkiadityaafela@gmail.com \\ 2110003600264 \\ Universitas Ekasakti Padang
}

\section{A. PENDahuluan}

Puji syukur kami panjatkan kehadirat Tuhan Yang Maha Esa karena atas limpahan rahmat dan hidayahnya sehingga kami dapat menyelesaikan makalah kami yang berjudul “Antropologi Hukum"Pada makalah ini kami banyak mengambil dari berbagai sumber dan refrensi dan pengarahan dari berbagai pihak .oleh sebab itu, dalam kesempatan ini kami mengucapkan terima kasih sebesar-sebesarnya kepada semua pihak yang telah membantu dalam penyusunan makalah ini.

Penyusun menyadari sepenuhnya bahwa makalah ini sangat jauh dari sempurna, untuk itu kami sangat mengharapkan kritik dan saran yang bersifat membangun guna kesempurnaan makalah ini. Akhir kata penyusun mengucapkan terima kasih dan semoga makalah ini dapat bermanfaat untuk semua pihak yang membaca.

Antropologi secara etimologis berasal dari bahasa Yunani. Kata Anthropos berartimansia dan logos berarti ilmu pengetahuan. Jadi, antropologi adalah ilmu yangmempelajari manusia. Oleh karena itu antropologi didasarkan pada kemajuan yangtelah dicapai ilmu pengetahuna sebelumnya.Pitirim Sorokim mengatakan bahwa Sosiologi adalah suatu ilmu yang mempelajarihubungan dan pengaruh timbal balik antara aneka macam gejala-gejala sosial (gejalaekonomi dengan agama, keluarga dengan moral, hukum dengan ekonomi) dengangejala lainnya (nonsosial).Berbeda dengan pendapat Rouceke dan Warren yang 
mengatakan bahwa Sosiologiadalah ilmu yang mempelajari hubungan manusia dengan kelompok-kelompok. Nah berasarkan uraian di atas, maka Sosiologi adalah jelas merupakan ilmu sosialyang objeknya adalah masyarakat sebagai ilmu. Ia berdiri sendiri karena telahmemiliki unsur ilmu pengetahuan.Dalam ilmu antropologi hukum dipelajari juga mengenai Peran, Status ataukedudukan, Nilai, Norma dan juga Budaya atau kebudayaan. Kesemuanya inimerupakan hal-hal yang sangat erat kaitannya dengan ilmu antropologi hukum.

\section{B. PEMBAHASAN}

\section{Definisi Antropologi Hukum}

Antropologi berasal dari bahasa Yunani, Antropos yang artinya manusia dan Logos yang artinya ilmu. Ilmu tentang hayati terdiri dari:

1. Paleo Antropologi, yaitu mempelajari tentang asal usul manusia dan perkembangannya. Metode yang digunakan dengan penggalian fosil-fosil. Bagian yang dipelajari adalah organorgan dalam tubuh.

2. Antropologi Fisik, yaitu mempelajari bentuk-bentuk manusia, baik bagian dalam maupun bagian luar tubuh. Tujuannya mempelajari corak ragam manusia.

Pengertian antropologi secara umum adalah salah satu cabang ilmu sosial yang mempelajari tentang budaya masyarakat suatu etnis tertentu. Sedangkan menurut Kamus Oxford, antropologi merupakan studi tentang masyarakat yang termasuk budaya manusia serta perkembangannya. Hal ini juga bisa dikatakan sebagai studi tentang karakteristik biologis dan fisiologis manusia. Sehingga fungsi dari antropologi ialah untuk mengembangkan pengetahuan tentang manusia baik secara fisik maupun secara sosio-kultural. 


\section{Pengertian Antropologi Menurut Para Ahli}

Merujuk dari penjelasan tersebut, adapun pengertian antropologi menurut para ahli yang bisa menambah wawasanmu semakin luas, diantaranya:

\section{William A. Havilland}

Pengertian antropologi ialah studi yang fokus kepada manusia, guna menyusun generalisasi yang berguna mengenai tingkah lakunya, serta untuk mendapatkan pengertian yang lengkap mengenai keanekaragaman umat manusia.

\section{Rifhi Siddiq}

Menurut Rifhi Siddiq, pengertian antropologi merupakan ilmu yang mengkaji segala aspek yang ada pada kehidupan manusia, dimana di alamnya termasuk norma, seni, kebudayaan, ilmu pengetahuan, linguistik, serta teknologi.

\section{Koentjaraningrat}

Antropologi merupakan ilmu yang mempelajari aneka warna-warna, bentuk fisik suatu masyarakat serta kebudayaan-kebudayaan yang dihasilkan oleh umat manusia.

\section{Tulian Darwin}

Antropologi ialah ilmu yang berasal dari keinginan untuk membuktikan asal mula dan perkembangan yang terjadi pada manusia dengan melaksanakan berbagai macam penelitian yang di mulai dengan monyet di seluruh penjuru dunia.

\section{David Hunter}

Antropologi adalah ilmu yang lahir dari keingintahuan yang tidak terbatas tentang umat manusia.

Dari definisi tersebut, dapat disusun pengertian sederhana antropologi, yaitu sebuah ilmu yang mempelajari manusia dari segi keanekaragaman fisik serta kebudayaan (cara-cara 
berprilaku, tradisi-tradisi, nilai-nilai) yang dihasilkan sehingga setiap manusia yang satu dengan yang lainnya berbeda-beda.

\section{Pengertian Antropologi Hukum}

Pengertian antropologi hukum ialah cabang ilmu pengetahuan hukum yang mempelajari polapola sengketa dan penyelesaiannya pada masyarakat.

Sehingga kalau terjadi pelanggaran atau tindakan yang menyimpang dari norma sosial maka yang melanggar akan diberikan sanksi, baik dalam bentuk tindakan fisik, sanksi sosial ataupun sanksi lainnya yang mempunyai wewenang bertindak.

Namun, pendapat ini berbeda halnya dengan sebagaimana yang dikemukakan oleh Leopold Pospisil, bahwa tidak segala sesuatunya hanya diukur menurut ukuran yang berlaku dalam budaya itu sendiri.

Antropologi hukum adalah salah satu ilmu yang saat ini masih dalam tahap pertumbuhan. Ini mempelajari kekhasan bentuk hukum aktivitas manusia dalam periode sejarah yang berbeda dan dalam keadaan yang sama sekali berbeda. Bagi para peneliti, pengembangan bidang ini sangat penting karena membantu untuk mengenal keragaman hukum dunia dan untuk melihat hukum melalui sudut pandang persepsi perwakilan dari berbagai bangsa dan budaya.

Sebuah studi substantif tentang masalah antropologi hukum melalui pengelolaan dan koordinasi berbagai bidang kehidupan publik, korelasinya dengan praktik yang terbukti, memungkinkan para ilmuwan untuk membangun struktur yang jelas dari sistem hukum, untuk memahami internal untuk mengungkap mekanisme pembangunan dan simbiosis dari kelompok sosial. Dalam keadaan sekarang, ada minat besar dalam penelitian ilmiah jenis ini, terutama dalam studi sumber hukum yang diwakili oleh adat istiadat dan tradisi. 


\section{Sistem Antropologi Hukum}

Struktur antropologi hukum mencakup bagian-bagian berikut dari disiplin ilmu ini:

Informasi teoritis tentang negara dan hukum. Ini menyiratkan studi tentang aspek epistemologis, metodologis dengan maksud untuk penerapan hasil selanjutnya dalam praktik.

Ontologi hukum yang merupakan bidang ilmu pengetahuan tentang keberadaan manusia dalam hubungan hukum negara adalah hak, kebebasan, keistimewaan dan kewajiban yang berperan penting dalam pembentukan budaya hukum masyarakat.

Antropologi etnografi sebagai bagian dari yurisprudensi. Tujuan akhir dari bidang ilmu ini adalah untuk mendeskripsikan perubahan yang terjadi pada perilaku dan aktivitas manusia dengan evolusi norma hukum, adat istiadat yang dianut oleh masyarakat tradisional dan kuno, hubungan hukum dan konflik timbal balik, serta analisis komparatif terhadap usang dan sistem modern, dengan mempertimbangkan persepsi manusia.

$\begin{array}{llll}\text { Fungsi } & \text { dan } & \text { Tujuan } & \text { Antropologi }\end{array}$

Penelitian ilmiah di industri ini adalah hasil dari diferensiasi yang mendalam antara hukum yang ada dan aspek teoritis hukum. Antropologi dalam pengertian ini adalah disiplin ilmu pada dua tingkatan:

fase pertama adalah blok logis-filosofis informasi tentang hukum dan negara; fase kedua adalah kompleks yang diterapkan secara praktis, yang pengembangannya diperlukan untuk penerapan langsung dari pengetahuan yang diperoleh dalam aktivitas yang benar-benar legal.

$\begin{array}{lll}\text { Budaya } & \text { dan } & \text { Kebudayaan }\end{array}$

Kebudayaan hukum adalah kekuasaan yang digunakan oleh penguasa untuk mengatur masyarakat agar tidak melanggar kaidah-kaidah sosial yang telah ada dalam masyarakat. Hukum 
diperlukan meski telah ada kaidah atau norma dalam masyarakat, agar terdapat keteraturan dalam kehidupan manusia melalui hukum tertulis dengan sanksi yang nyata disamping norma dan kaidah yang sanksinya lebih bersifat sosial atau akhirat. Sebagai Ilmu Pengetahuan, Antropologi Hukum dicirikan oleh 3 (tiga) hal yaitu adanya: Objek, Metode, dan Sistem

Antropologi Hukum sebagai ilmu pengetahuan yang merupakan spesialisasi dari Antropologi Budaya, memiliki karakter:

1. Antropologi Hukum, adlah Ilmu pengetahuan (logos) tentang Manusia (antropos) yg berhubungan dengan Hukum

2. Manusia, adlah manusia yg hidup bermasyrakat, masyarakat yg masih sederhana budayanya (primitif) dan yg sudah Maju (modern)

3. Budaya adalah Budaya Hukum, yaitu segala bentuk perilaku budaya manusia yg mempengaruhi Masalah Hukum

Budaya adalah milik bersama yang perlu dipertahankan atau dilestarikan. Budaya hukum adalah tanggapan masyarakat terhadap suatu perbuatan yang dianggap baik, yang hal ini juga bergantung pada sikap penegak hukum.

Nilai budaya atau Postulat adalah nilai yang ada dalam masyarakat modern dan masyarakat sederhana yang dinilai baik atau dipertahankan.

Masalah Hukum tidaklah hanya pada masalah hukum yang normatif (undang-undang), atau masalah hukum yang merupakan pola perilaku yg sering terjadi (hukum adat ), tetapi juga masalah budaya terhadap suatu masalah Hukum, dikarenakan adanya Faktor Budaya yang mempengaruhinya, yaitu:

1. Faktor-faktor Budaya yg melatarbelakangi Masalah Hukum ; misalnya, Cara-cara 
menyelesaikan Masalah Perselisihan dikalangan Orang Batak, tidak sama dengan orang Minang, Jawa, Bali, Maluku dan lainya

2. Cara-cara tersebut menjai Objek perhatian Antropologi Hukum

\section{PENUTUP}

Antropologi adalah ilmu yang mempelajari manusia. Oleh karena itu antropologi didasarkan pada kemajuan yang telah dicapai ilmu pengetahuan sebelumnya. Pengertian Antropologi dapat dilihat dari 2 sisi yaitu Antropologi sebagai ilmu pengetahuan artinya bahwa Antropologi merupakan kumpulan pengetahuan-pengetahuan tentang kajian masyarakat dan kebudayaan yang disusun secara sistematis atas dasar pemikiran yang logis. Dan pengertian Antropologi yang kedua adalah cara-cara berpikir untuk mengungkapkan realitassosial dan budaya yang ada dalam masyarakat dengan prosedur dan teori yang dapat dipertanggungjawabkan kebenarannya secara ilmiah.

Setelah di kaji kita dapat mengemukakan hasilnya bahwa manfaat di dalam antropologi hukum sangat luas.Antropologi hukum telah memberikan kontribusi yang sangat besar bangi perkembangan ilmu hukum.Dan kesimpulan yang dapat diambil adalah dimana pun kita ,kita tidak akan pernah jauh dari hukum selama kita berada di Negara hukum.

Peranan adalah aspek dinamis dari kedudukan, yaitu seorang yang melaksanakan hak-hak dan kewajibannya.Status adalah tempat atau posisi seseorang dalam suatu kelompok sosial. Sedangkan kedudukan sosial (social status) artinya tempat seseorang secara umum dalam masyarakatnya sehubungan dengan orang lain, dalam arti lingkungan pergaulannya, prestisenya, dan hak-hak serta kewajiban-kewajibannya.

Namun untuk mempermudah dalam pengertiannya maka dalam kedua istilah di atas akan dipergunakan dalam arti yang sama dan digambarkan dengan istilah "kedudukan" (status) 
saja. Nilai (Nilai Sosial) adalah nilai yang dianut oleh suatu masyarakat, mengenai apa yang dianggap baik dan apa yang dianggap buruk oleh masyarakat. Norma adalah seluruh kaidah dan peraturan yang diterapkan melalui lingkungan sosialnya. Budaya adalah hal-hal yang berkaitan dengan budi dan akal manusia. Kebudayaan merupakan keseluruhan pengertian, nilai, norma, ilmu pengetahuan serta keseluruhan struktur-struktur sosial, religius, dan lainlain, tambahan lagi segala pernyataan intelektual dan artistik yang menjadi ciri khas suatu masyarakat.

\section{DAFTAR PUSTAKA}

Darmini Roza dan Laurensius Arliman S, Peran Pemerintah Daerah Di Dalam Melindungi Hak Anak Di Indonesia, Masalah-Masalah Hukum, Volume 47, Nomor 1, 2018. https://doi.org/10.14710/mmh.47.1.2018.10-21

Laurensius Arliman S, Peranan Metodologi Penelitian Hukum di Dalam Perkembangan Ilmu Hukum di Indonesia, Soumatera Law Review, Volume 1, Nomor 1, 201. http://doi.org/10.22216/soumlaw.v1i1.3346. 